University of Nebraska - Lincoln

DigitalCommons@University of Nebraska - Lincoln

December 1984

\title{
Segregation of copper to the surface of copper-nickel alloys
}

Peter A. Dowben

University of Nebraska-Lincoln, pdowben@unl.edu

Follow this and additional works at: https://digitalcommons.unl.edu/physicsdowben

Part of the Physics Commons

Dowben, Peter A., "Segregation of copper to the surface of copper-nickel alloys" (1984). Peter Dowben Publications. 69.

https://digitalcommons.unl.edu/physicsdowben/69

This Article is brought to you for free and open access by the Research Papers in Physics and Astronomy at DigitalCommons@University of Nebraska - Lincoln. It has been accepted for inclusion in Peter Dowben Publications by an authorized administrator of DigitalCommons@University of Nebraska - Lincoln. 


\title{
Brief Reports
}

Brief Reports are short papers which report on completed research which, while meeting the usual Physical Review standards of scientific quality, does not warrant a regular article. (Addenda to papers previously published in the Physical Review by the same authors are included in Brief Reports.) A Brief Report may be no longer than 31/2 printed pages and must be accompanied by an abstract. The same publication schedule as for regular articles is followed, and page proofs are sent to authors.

\section{Segregation of copper to the surface of copper-nickel alloys}

\author{
P. A. Dowben \\ Department of Physics, Syracuse University, Syracuse, New York 13210
}

(Received 6 July 1984)

\begin{abstract}
Copper segregation profiles at the surfaces of $\mathrm{Cu}_{17} \mathrm{Ni}_{83}(111)$ and $\mathrm{Cu}_{17} \mathrm{Ni}_{83}(100)$ have been calculated by a semiempirical procedure based upon previously published data. These profiles indicate that surface enrichment of copper is not limited only to the topmost layer but occurs for several layers away from the surface as well. A comparison of the calculated segregation profiles based upon the experimental results for the (100) and (111) surfaces of $\mathrm{Cu}_{17} \mathrm{Ni}_{83}$ do not agree with predictions based upon thermodynamic models of segregation.
\end{abstract}

Recently, ${ }^{1}$ the segregation profile for chromium to the surface of a $\mathrm{Fe}_{72} \mathrm{Cr}_{28}(110)$ crystal has been determined using $\mathrm{x}$-ray photoelectron spectroscopy. Model segregation profiles of chromium were employed to generate expected iron to chromium $x$-ray photoemission spectroscopy (XPS) signal ratios for the $\mathrm{Fe}$ and $\mathrm{Cr} 2 p$ XPS core levels as well as for the $\mathrm{Fe}$ and $\mathrm{Cr} 3 p$ XPS core levels. These models were then compared to the experimental results corrected for photoemission cross section and analyzer efficiency. This procedure, because of the different electron mean free paths for the $2 p$ and $3 p$ XPS signals, predicted chromium segregation profiles that were in good agreement with the profiles determined directly by $\mathrm{Ar}^{+}$ion bombardment experiments. Furthermore, these results indicated that a segregation profile of Gaussian or exponential shape occurs for equilibrium segregation at binary alloy surfaces.

Employing different photoemission take-off angles for a given XPS core level changes the electron mean free path perpendicular to the surface. By employing the $\mathrm{Cu} 2 p_{3 / 2}$ to $\mathrm{Ni} 2 p_{3 / 2}$ Al $K \alpha$ XPS signal ratios reported by Wendelt and Brundle, ${ }^{2,3}$ copper segregation profiles at the surfaces of $\mathrm{Cu}_{17} \mathrm{Ni}_{83}(111)$ and $\mathrm{Cu}_{17} \mathrm{Ni}_{83}(100)$ may be calculated since the results were obtained for two different $\left(45^{\circ}\right.$ and $75^{\circ}$ off normal) emission angles. The nickel $2 p_{3 / 2}$ signal, as a fraction of the total $2 p_{3 / 2}$ signal from copper and nickel for model Gaussian and exponential segregation profiles, is approximately

and

$$
C_{\mathrm{Ni}}=0.83 \frac{\sum_{i=0}^{n}\left\{\left[1-S \exp \left(-i d^{2} / G\right)\right] \exp \left(-i d / \lambda_{e}\right)\right\}}{\sum_{i=0}^{n} \exp \left(-i d / \lambda_{e}\right)}
$$

$$
C_{\mathrm{Ni}}=0.83 \frac{\sum_{i=0}^{n}\left\{[1-S \exp (-i d / G)] \exp \left(-i d / \lambda_{e}\right)\right\}}{\sum_{i=0}^{n} \exp \left(-i d / \lambda_{e}\right)},
$$

respectively, where $\lambda_{e}$ is the electron mean free path, $d$ the crystal layer spacing, while $S$ and $G$ are parameters chosen for best agreement with experiment. 1,4 An "average" mean free path of $7.1 \AA$ for $45^{\circ}$ emission and $2.6 \AA$ for $75^{\circ}$ emission from the $\mathrm{Cu}$ and $\mathrm{Ni} 3 p_{3 / 2}$ XPS photoelectrons may be assigned. Using these electron mean free paths, correcting for analyzer efficiency (assumed to increase with the reciprocal of energy), as well as photoemission cross section, ${ }^{5}$ the published experimental XPS data, ${ }^{3}$ shown in Table I, are consistent with the model segregation profiles shown in Fig. 1. These results assume equilibrium segregation occurred at $\sim 800 \mathrm{~K}$ prior to taking the XPS measurements reported. ${ }^{2,3}$

The calculated segregation profiles shown differ from the predictions derived using theoretical models of surface segregation for copper in copper-nickel alloys. ${ }^{6,7}$ Thermodynamic calculations only predict copper enrichment of the topmost layer or two. Clearly, the analysis of the data of Wandelt and Brundle, shown in the figure, indicates enrichment of copper occurs for as many as five layers. Thus,

TABLE I. Apparent fractional surface concentrations of copper and nickel in $\mathrm{Cu}_{17} \mathrm{Ni}_{83}$, as measured by XPS (Refs. 2 and 3), and corrected for analyzer efficiency and photoemission cross section. The crystal layer spacing is also indicated.

\begin{tabular}{cccc}
\hline \hline & $C_{\mathrm{Ni}}$ & $C_{\mathrm{Cu}}$ & $\begin{array}{c}d \text { spacing } \\
(\AA)\end{array}$ \\
\hline $\begin{array}{c}\mathrm{Cu}_{17} \mathrm{Ni}_{83}(100) \\
45^{\circ} \text { emission }\end{array}$ & 0.48 & 0.52 & 1.8 \\
$\begin{array}{c}\mathrm{Cu}_{17} \mathrm{Ni}_{83}(100) \\
75^{\circ} \text { emission }\end{array}$ & 0.29 & 0.71 & 1.8 \\
$\begin{array}{c}\mathrm{Cu}_{17} \mathrm{Ni}_{83}(111) \\
45^{\circ} \text { emission }\end{array}$ & 0.55 & 0.45 & 2.05 \\
$\begin{array}{c}\mathrm{Cu}_{17} \mathrm{Ni}_{83}(111) \\
75^{\circ} \text { emission }\end{array}$ & 0.31 & 0.69 & 2.05 \\
\hline \hline
\end{tabular}



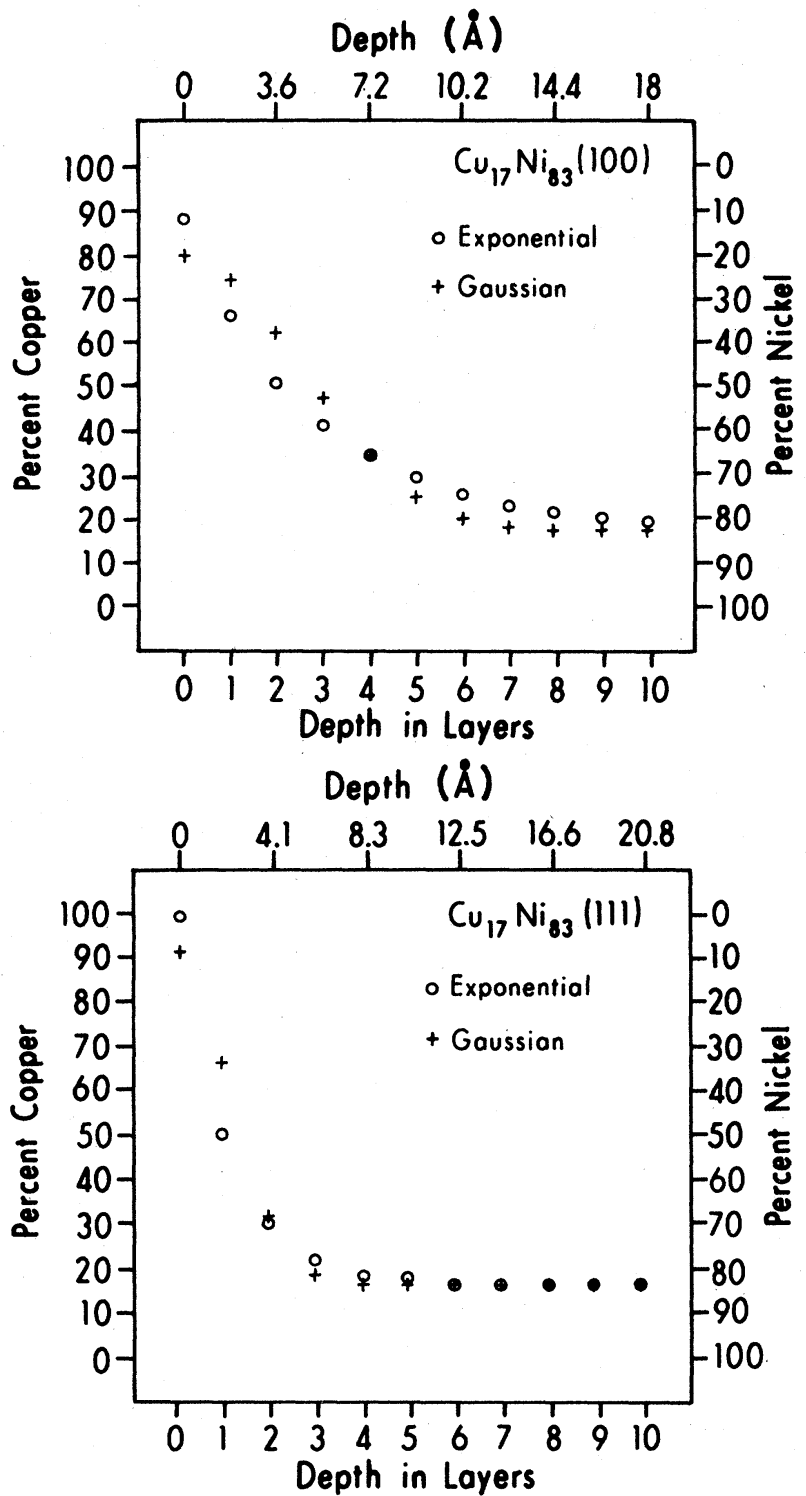

FIG. 1. Concentration profiles for copper and nickel calculated from the XPS $2 p_{3 / 2}$ core-level signals reported by Wandelt and Brundle (Refs. 2 and 3 ) for $45^{\circ}$ and $75^{\circ}$ emission. The profile is assumed to have either Gaussian $(+)$ or exponential $(0)$ shape. The surface is placed at zero.

segregation in binary alloys does not appear to be limited to the top one or two layers as suggested by theoretical models. This result is consistent with the large selvedge enrichment found for chromium in $\mathrm{Fe}_{72} \mathrm{Cr}_{28}(110)$ for as many as 20 layers in depth from the surface. ${ }^{1}$ Copper enrichment of more than the topmost surface layer has also been reported for $\mathrm{Cu}_{5} \mathrm{Ni}_{95}$ alloys. ${ }^{8}$

For just the topmost surface layer alone, the calculated segregation profiles based upon the data of Wandelt et al..$^{2,3}$ for $\mathrm{Cu}_{17} \mathrm{Ni}_{83}(111)$ and $\mathrm{Cu}_{17} \mathrm{Ni}_{83}(100)$ are, in general, in good agreement with the theoretical surface concentration of copper at the surface layer. For equilibrium at $973 \mathrm{~K}$, $\mathrm{Kumar}^{7}$ has predicted that $\sim 76 \%$ of the surface is copper for $\mathrm{Cu}_{17} \mathrm{Ni}_{83}(111)$. For equilibrium at $750 \mathrm{~K}$, Donnelly and King $^{6}$ have predicted that for $\mathrm{Cu}_{17} \mathrm{Ni}_{83}(111)$, the topmost surface layer is $-85 \%$ copper and for $\mathrm{Cu}_{17} \mathrm{Ni}_{83}(100)$ the surface is $90 \%$ copper. The semiempirical calculated profiles derived here indicate $80 \%$ to $90 \% \mathrm{Cu}$ at the $\mathrm{Cu}_{17} \mathrm{Ni}_{83}(100)$ surface and $90 \%$ to $100 \%$ at the $\mathrm{Cu}_{17} \mathrm{Ni}_{83}(111)$ surface (at $\sim 800 \mathrm{~K})$. Low-energy ion scattering results ${ }^{9}$ also compare favorably, since the surface of the $\mathrm{Cu}_{20} \mathrm{Ni}_{80}$ alloy was found to be $\sim 84 \%$ copper at $800 \mathrm{~K}$. These results are summarized in Table II.

Generally, ${ }^{3,6}$ one would expect more copper at the (100) surface as compared to the (111) surface for copper-nickel alloys. While the calculated copper segregation to the surface region is greater for the (100) surface than the (111) surface, unfortunately the surface concentration reported here for the topmost layer indicates that more copper segregation occurs on the (111) surface than the (100) surface. This defect in the semiempirical calculated segregation profiles is not as yet understood. Electron mean free paths may differ for each crystal face, though small changes in $\lambda_{e}$ do not seriously alter the results shown in Fig. 1.

A better understanding of surface segregation both at the surface and the surface region must be sought. Despite the considerable attention paid to copper segregation in coppernickel alloys, further work on selvedge enrichment, crystal face specificity in surface segregation, and electron mean free paths is required.

This work was initiated at the Fritz Haber Institut der Max Planck Gesellschaft. The author would like to thank Deutsche Forschungs Gemeinschaft (Sonderforschung Bereicht 6) and Syracuse University for their financial support. The author also acknowledges the useful suggestion of C. R. Brundle concerning the mean free path.

TABLE II. Estimated copper concentration at the surface and selvedge for copper-nickel alloys similar to $\mathrm{Cu}_{17} \mathrm{Ni}_{83}$.

\begin{tabular}{|c|c|c|c|c|c|}
\hline Material & $\begin{array}{l}\text { Method of } \\
\text { determination }\end{array}$ & $\begin{array}{l}\text { Temperature } \\
\text { (K) }\end{array}$ & $\begin{array}{c}\text { Percent } \\
\mathrm{Cu} \text { at } \\
\text { surface }\end{array}$ & $\begin{array}{l}\text { Substantial } \\
\text { copper segregation } \\
\text { in the selvedge }\end{array}$ & Reference \\
\hline $\mathrm{Cu}_{17} \mathrm{Ni}_{83}(111)$ & Theory & 973 & $\sim 76$ & No & 7 \\
\hline $\mathrm{Cu}_{17} \mathrm{Ni}_{83}(111)$ & Theory & 750 & $\sim 85$ & No & 6 \\
\hline $\mathrm{Cu}_{17} \mathrm{Ni}_{83}(100)$ & Theory & 750 & -90 & No & 6 \\
\hline $\mathrm{Cu}_{20} \mathrm{Ni}_{80}$ & Ion scattering & 800 & 84 & $\cdots$ & 9 \\
\hline $\mathrm{Cu}_{17} \mathrm{Ni}_{83}(111)$ & Semiempirical & 800 & $90-100$ & Yes & This work \\
\hline $\mathrm{Cu}_{17} \mathrm{Ni}_{83}(100)$ & Semiempirical & 800 & $80-90$ & Yes & This work \\
\hline
\end{tabular}


1P. A. Dowben, M. Grunze, and D. Wright, Surf. Sci. 134, L524 (1983).

${ }^{2}$ C. R. Brundle and K. Wandelt, J. Vac. Sci. Technol. 18, 537 (1981).

${ }^{3}$ K. Wandelt and C. R. Brundle, Phys. Rev. Lett. 46, 1529 (1981).

${ }^{4}$ P. A. Dowben and M. Grunze, J. Electron. Spectrosc. Relat. Phenom. 28, 249 (1983).

5J. H. Scofield, J. Electron. Spectrosc. Relat. Phenom. 8, 129
(1976).

${ }^{6}$ R. G. Donnelly and T. S. King, Surf. Sci. 74, 89 (1978).

${ }^{7}$ V. Kumar, Phys. Rev. B 23, 3756 (1981).

${ }^{8}$ P. R. Webber, C. E. Rojas, P. J. Dobson, and D. Chadwick, Surf. Sci. 105, 20 (1981).

${ }^{9}$ H. H. Brongersma, M. J. Sparnaay, and T. M. Buck, Surf. Sci. 71, 657 (1978). 